\title{
25 YEARS OF THE TETRA STANDARD AND TECHNOLOGY FOR CONTEMPORARY DIGITAL TRUNKING SYSTEMS OF PROFESSIONAL MOBILE RADIO COMMUNICATIONS
}

\author{
Slađan M. Svrzić \\ Tesla Systems Ltd, Belgrade, Republic of Serbia, \\ e-mail: milosavljevic_svrzic@hotmail.com, \\ ORCID iD: (Dhttps://orcid.org/0000-0003-4525-9844
}

DOI: 10.5937/vojtehg69-29340; https://doi.org/10.5937/vojtehg69-29340

FIELD: Telecommunications

ARTICLE TYPE: Original scientific paper

\begin{abstract}
:
Introduction/purpose: For the construction of functional mobile radio communication systems today, the trunking systems of digital mobile radio communications are almost exclusively used, the main representative of which is the system with the application of TETRA standards. This article describes the beginnings and historical development of this standard, with the activities of ETSI and TETRA MoU in the fight for the availability and harmonization of the frequency spectrum.

Methods: A description of relevant issues of the origin and development of the TETRA 1 standard is given as well as the analysis of the characteristic moments of the innovated TETRA 2 standard.

Results: This article describes the beginnings and historical development of this standard, with the activities of ETSI and TETRA MoU in the fight for the availability and harmonization of the frequency spectrum. It also systematize the use of the key TETRA systems in the world and shows its share in the world market by sectors, emphasizing the dilemma of its further development at the crossroads after 25 years of existence. Also, a basic overview of the TETRA 1 standard is given while the basic elements and the principle of its application are described. The innovated TETRA 2 standard and the improvements achieved in the way of data transmission are described in more detail; the process of interoperability certification and, in connection with that, the entry of TETRA into the North American market is emphasized. The parameters selected for advanced data transfer according to the TETRA 2-TEDS standard are presented and analyzed, together with an overview of some limitations during practical application.
\end{abstract}


Conclusion: In the conclusion, the current moment of TETRA is analyzed with a focus on its future after 25 years of development, emohasizing a possibility of modernizing and improving the TETRA network of the Ministry of the Interior of Serbia for the needs of the MoD and the Serbian Armed Forces.

Key words: mobile radio communications-MR, public mobile radio communication system-PAMR, professional mobile radio communication system-PMR, area-interface-Al, digital trunking system of mobile radio communications-TETRA, TETRA enhanced data service-TEDS, European telecommunications standardization instituteETSI.

\section{Introduction}

The earliest beginnings of TETRA (Terrestrial Trunked Radio) date back to 1989, when four leading European companies for the production of mobile radio equipment: Ericsson, Motorola Solutions, Nokia and Philips, began work on the development of digital trunking systems for mobile radio communications, called MDTRS (Mobile Digital Trunked Radio System). During the same year, work began in North America on the development of a new, accompanying Standard for Interoperable Digital Mobile Radio Communications for Voice Transmission, now known as P25 (Project 25). While the development of the P25 standard was the responsibility of the North American public-safety community (NAPsC), TETRA was developed under the auspices of the European Telecommunications Standards Institute (ETSI), supported by many manufacturers and equipment vendors, system users and, of course, regulatory bodies. (Ovčinnikov et al, 2000), (Svrzić \& Ćosović, 2002a), (Swan, 2015)

From the very beginning, the development of TETRA was a cornerstone for establishing a new standard for UHF (Ultra High Frequency) mobile radio communication MR (Mobile Radio), with unique recommendations. Thus, during 1993, the support of the manufacturers of equipment for Functional Mobile Radio Communications SystemsPMR (Professional Mobile Radio) significantly improved and the way was paved for the emergence of a strong and solidary association of sellers of this type of equipment. This enabled the TETRA MoU (TETRA Memorandum of Understanding) to be formed and put into operation in December 1994, uniting the then most important manufacturers and sellers of PMR equipment. As a united organization of producers and sellers, the TETRA MoU association played a very important role not only for the permanent development of TETRA but also for maintaining 
interoperability, for creating new market opportunities, as well as for fight against fierce competition which, uderstandably, advocated other standards and technologies. (Svrzić \& Ćosović, 2002a), (Swan, 2015)

The MDTRS standard grew into a standard called TETRA (TransEuropean Trunked RAdio) in 1991, which was only an approximate interpretation of the current name of the TETRA standard. Namely, as ambitions on a global level were immediately tied to the standard, the acronym "TETRA" is today interpreted as a natural abbreviation derived from the word TErrestrial Trunked Radio. An important date in the emergence of TETRA is December 1995, when ETSI adopted and approved the new TETRA $V+D$ radio interface-TAI (TETRA Voice plus Data Air interface), as a complete European Telecommunications Standard-ETS for integrated transmission speech and signal data, ETSI EN 300 392-2, although TETRA even then showed its undisguised ambitions for application in the entire world market (ETSI, 2001). In contrast, it is believed that TETRA was not a standard associated with the then existing Public Access Mobile Radio System (PAMR) from the beginning, nor was PAMR part of TETRA. Namely, TETRA $V+D$ has proven to be a flexible standard for digital mobile radio communication systems whose infrastructure is formed by switching elements, a number of base and many mobile radio stations as a highly redundant and flexible system for all requirements, making it ideal for regular business and functional mobile radio communications, as well as for mobile radio communications in conditions of critical situations for public safety. The standard includes the necessary recommendations-specifications (type: ETSI EN $300 \mathrm{xxx}$ ) for group, broadband and emergency calls, then for quick access to the system (which is usually shorter than $300 \mathrm{~ms}$ ), for Trunking Mode Operation-TMO and Direct Mode Operation-DMO type of work, for different levels of application of information encryption, for telephony with participants from functional networks with PABX and from public networks-PSTN (including full duplex) and support for smooth operation of checkpoints (Control -management and dispatch centers) (Swan, 2015).

At the time of the TETRA $V+D$ standard, the data transfer rate in it was relatively low and comparable to the data transfer rate of other technologies, which is no longer valid today, but it should be noted that the TETRA standard already offered a powerful system of Status Messages-StM and Short Written Messages-SDM, as well as a special data package related to the execution of special tasks in the field in critical situations. The entire industry which surrounded TETRA was already determined at that time not to allow the new standard to be 
undermined and its strengthening to be hindered. Therefore, the European Regulatory Organization for Safety and Protection of People at Work formed a special working group of experts, with the task of clarifying to potential clients at the (very) beginning of the existing (and turned out to be false) beliefs about the alleged danger to OSH work by pulsed radiation of mobile TETRA terminals. Namely, the entire world industry of mobile radio communications today is very serious and comprehensive in approaching the solution of issues in the field of $\mathrm{OSH}$, so it invests significant funds for that. In that respect, everything about TETRA, in relation to them, does not differ at all. Therefore, the RF (Radio Frequency) sensitive work environment was protected from the very beginning by a novelty, which is characterized by TETRA terminals, and which is called Transmit Inhibit Mode (TMI). It enables users of the TETRA terminal to perform their duty unhindered in environments where sensitive medical equipment is present (in healthcare centres and hospitals) or electronic measuring equipment in laboratories and in the field (instruments, speedometers, breathalyzers, etc.), all without interfering with the operation of the equipment or compromising the accuracy of the obtained measurement results (Swan, 2015).

\section{Frequency spectrum allocation for TETRA}

The availability and harmonization of the frequency spectrum, that is, the spectral efficiency, was one of the key moments for the worldwide success of the TETRA standard. Namely, an open MR standard, which implies that equipment from different manufacturers, can be used in a single radio network, must offer the system owner, on the one hand, sufficient spectral efficiency, with the possibility of choosing equipment from different manufacturers, and at the same time, on the other hand, enable the achievement of reasonable economy on the existing scale in order to maintain a broadly competitive world market of sellers. Therefore, immediately, i.e. in the early 1990s, work began on defining the adjusted bandwidth for MDTRS, which was managed by the European Radiocommunications Office-ERO from the Community of European Conference of Postal and Telecommunications Administrations-CEPT. In addition, in the middle of the same year, primarily thanks to consultations with NATO and their cooperation, as well as the cooperation of some other radio spectrum users in Europe, within the frequency range 380 to $400 \mathrm{MHz}$, which is strictly intended for users in security public services for the needs of TETRA in Europe, two new subbands of frequencies of $5 \mathrm{MHz}(380-385 / 390-395 \mathrm{MHz})$ were 
defined, which is 200 communication radio channels with a width of $25 \mathrm{kHz}$.

The mentioned work within CEPT also gave positive results, as for the needs of using TETRA in various commercial services in Europe, four more subbands of frequencies in parts of the spectrum 410-430 / $450-470 \mathrm{MHz}$ were defined (which is another 800 radio channels $25 \mathrm{kHz}$ wide) and $870-876 / 915-921 \mathrm{MHz}$ (which is an additional 240 radio channels $25 \mathrm{kHz}$ wide). In addition, the mentioned parts of the spectrum, 380-395 $\mathrm{MHz}$ and $410-430 \mathrm{MHz}$, which are designated as the basic band, together with the newly allocated auxiliary band $870-876 \mathrm{MHz}$, have also become widely available for use by TETRA in other regions of the world (meaning those outside Europe). Despite initial concerns, whether such a specific radio spectrum width will be sufficient for the frequency plan, and whether it will allow the required density of TETRA network elements, necessary for good radio coverage and adjusted capacity of communication channels, to be implemented in the field, improved technical the RF characteristics of the third generation TETRA terminals have allowed mobile participants to operate successfully on the combined broadband configuration of both parts of the basic band, i.e. from 380 to $430 \mathrm{MHz}$. This means that since then, by combining the basic spectral bands $380-400 \mathrm{MHz}$ and $410-430 \mathrm{MHz}$, it has been possible to provide additional radio coverage and increase the capacity of communication channels, wherever necessary (of course, if spectrum is available).

It should be noted that TETRA has already unequivocally proven its pronounced spectral efficiency in this area, as it has enabled, from the very beginning, a large number of national networks operating today to function simultaneously and successfully, using only the basic part of the spectrum ( 380 up to $400 \mathrm{MHz}$ ) that is, without the use of assigned TETRA supplementary radio spectrum bands. (Svrzić \& Ćosović, 2002a, 2002b), (Swan, 2015)

\section{The most famous realized TETRA systems in the} world and an overview of the world TETRA market

The Autonomous Island of Jersey, located in the English Channel, was the country where, in June 1996, the world's first TETRA network was activated, and then several test systems were set up across Europe over the next few years. At the same time, after the approval for the use of TETRA in large national networks had been obtained, the planning and procurement of TETRA systems for the support of functional mobile 
radio communications in the public security sector began. Based on that, by the end of 2000, in 21 different countries of the world, the construction of 32 TETRA networks of different levels had already been completed or was being completed. The first major European achievements in the application of TETRA for the construction of mobile radio communications include the following realized projects:

- the national network "PSRCP / AIRWARE" in Great Britain, for the construction of which a contract was signed in 1977, but the works were completed and the system was put into operation in 2001,

- the national network "VIRVE" in Finland, whose planning began in 1995, construction work began in 1998, and operational use at the national level began in 2002,

- the national network "ASTRID" in Belgium, whose planning and construction lasted from 1995 to 2002, when it was introduced into operational use at the national level,

- the national network "C2000" in the Netherlands, whose construction works started in 1999, and the complete infrastructure was completed and the system established at the national level in 2004, and

- the national network "BD-BOS" in Germany, for the construction of which an extensive research was started in 2007 and which was supposed to be intended for the police exclusively. This network was completed only a few years ago and today is the largest TETRA network in the world.

From today's point of view in the modern world, TETRA serves almost every segment of the global PMR market and is present on all continents. The global percentage of TETRA users by social and economic sectors is shown in the diagram in Figure 1. The diagram shows that the largest part of the global TETRA market of $33 \%$ is intended for Public Security Sector, in which TETRA began to be used initially. Across Europe and the Middle East, there are significant national TETRA networks for the needs of Security Services, which regularly operate in emergency and critical situations, as well as for the needs of Rapid Response Organizations. In that sense, the key aspect of TETRA is that it allows the system owner in regular radio communications full autonomy of work, and that when acting in emergency and crisis situations, it provides full interoperability between different services and agencies. The second largest world TETRA market share, with a $24 \%$ share, covers the owners of PMR from the Transport Sector. This part of the TETRA market is growing fastest today, especially in systems for fast and mass transport of people and goods, as well as in large ports and 
airports, which account for an additional 5\% share. It should be noted that the pioneering projects for the implementation of TETRA in the USA were located within this sector, which started only after the long-awaited (until September 2012) approval of the FCC (Federal Communications Commission) for its smooth implementation on the North American continent. (Swan, 2015)

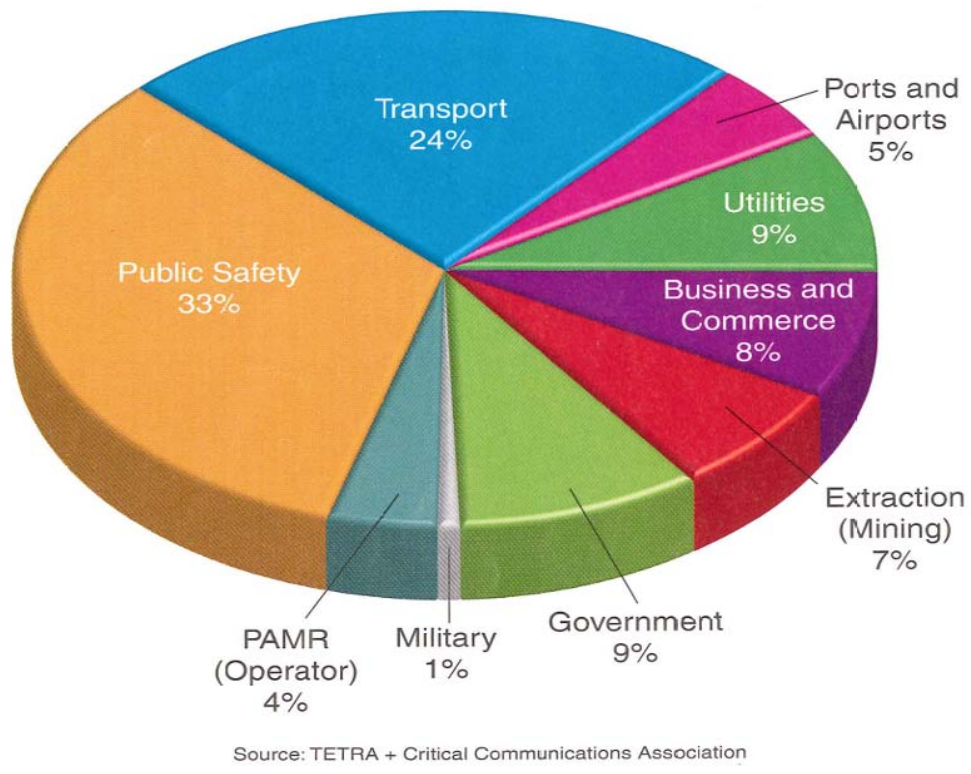

Figure 1 - Overview of the percentage share of TETRA users in the world PMR market (Swan, 2015)

Puc. 1 - Обзор процентной доли пользователей TETRA на мировом рынке PMR (Swan, 2015)

Слика 1 - Приказ процентуалног удела корисника TETRA на светском тржишту PMR (Swan, 2015)

The great success of TETRA, as well as its high percentage share in the world PMR market, has attracted a large number of equipment manufacturers, followed by application developers, as well as suppliers of peripherals and services. For these reasons, the TETRA market continues to grow permanently. For example, in 2013, IHS announced that a total of 600,000 sets of new TETRA terminals were being delivered to the global market, which is a significant number for a part of almost 3.2 million TETRA terminals already in operation in the world. A GSMA source stated that this number of approximately 4 million mobile 
terminals in various TETRA networks in 2015 realized a colossal 6.5 billion active connections. The analysis of the existing TETRA market over time shows that, from year to year, there has been a steady increase in the number of activated TETRA terminals in the world of $8 \%$, which today results in approximately 6 million terminals worldwide (Swan, 2015). In addition, the results of the analysis of the global distribution of implemented TETRA 1 systems up to the first half of the 2000s are impressive, primarily for the needs of functional users, but (in some cases) for public system operators as well, as shown in Figure 2 (ETSI, 2004).

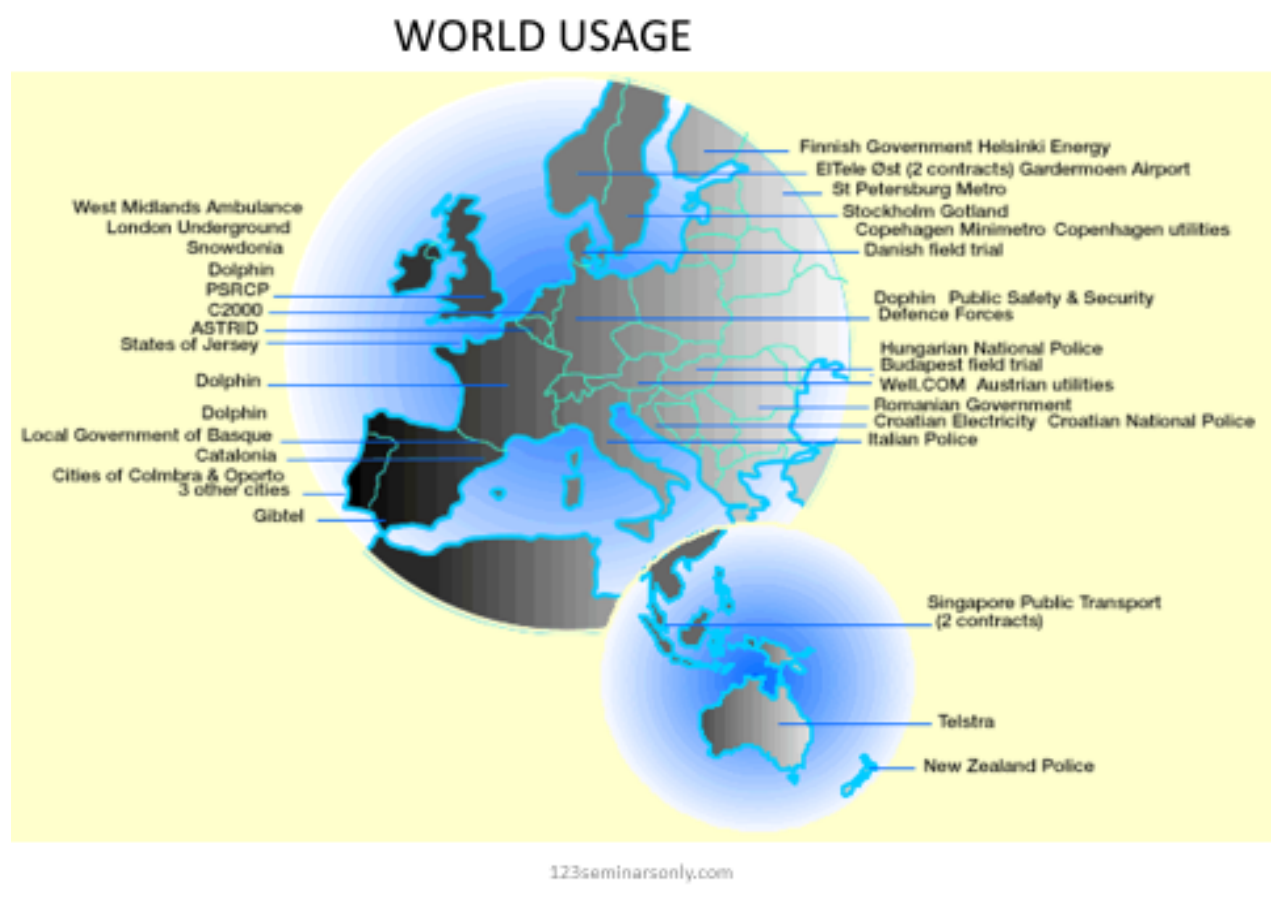

Figure 2 - Overview of the implemented TETRA Systems in the world up to the first half of the 2000s (ETSI, 2004)

Puc. 2 - Обзор внедренных систем TETRA в мире до первой половины 2000-х годов (ETSI, 2004)

Слика 2 - Преглед реализованих система TETRA у свету до прве половине 2000$\operatorname{mux}(E T S I, 2004)$

It can be seen from the figure that, in Serbia's neighboring countries, significant capacities of the TETRA 1 system were already built at that time, as follows: 
- for the Hungarian National Police,

- for the Government of Romania,

- for the national police and the Croatian power industry,

- for the Italian National Police, and

- for a set of utility companies (electricity, gas, water) in Austria.

At that time, Serbia was also considering the construction of modern mobile radio connections based on the principle of digital trunking according to the TETRA 1 standard. This primarily referred to the Oil Industry of Serbia (NIS), which already in the mid-1990s wanted to replace its outdated and insufficiently functional, analog and conventional system of mobile radio communications. In that sense, in order to build a completely new functional system of digital telecommunications, during 2001 and early 2002, NIS conducted a comprehensive market research of Analog Trangig Systems Standard MPT-1327 (Svrzić \& Ćosović, 2000) and Digital Trangig Systems Standard TETRA 1. Based on the comparative analyses and the obtained results as well as on the a priori determined positions of the NIS management on the need to favor digital connections, in March 2002, within the "Study of NIS Radio Connection M-21 (part-V)" the "Preliminary design for construction NIS mobile radio communication system in digital trunking technology " was prepared with the Technical Solution, which favoured Rohde \& Schwarz "ACCESSNETT" TETRA V + D network (Rohde \& Schwarz, 1999b) for the coverage of the territory of the Republic of Serbia (primarily in the areas where business activities of NIS were performed). (Jorgić \& Svrzić, 2002)

As for the Serbian Armed Foces (SAF), the then decision-makers of the General Staff-Directorate for Telecommunications took the position that such a system was too comfortable and expensive for independent construction in the army, since it is primarily intended for public security and safety services, and created to operate in crises. Therefore, the Ministry of the Interior of Serbia (their expert telecommunications service) was entrusted to conduct a market research program and procurement of equipment, on the basis of which (in the second half of the 2000s) works began on the construction of the National TETRA network type "DIMETRA/System Release 6.2" Motorola (Motorola Solutions, 2008). Of course, today the MoD and the SAF are regular participants in that network, with a large number of handheld and car mobile radios, and with the contribution to its infrastructure of 2 built fixed base radio stations (in constant use) and a couple of mobile base radio stations (for temporary use), but with little authority for its own, i.e. autonomous operational modeling or control (Krstić \& Marjanović Jakovljević, 2018). 


\section{A crossroads for TETRA after 25 years of experience}

In November 2011, the existing TETRA MoU Association changed its name to TETRA + Critical Communications Association-TCCA to demonstrate its focus on broadband digital mobile radio communications for professional users. In fact, the Critical Communications Broadband Group (CCBG) then paved the way for the development and adoption of a global common standard for mobile broadband, as well as a solution for all those users who operate on a daily basis performing dangerous tasks, or regular activities in critical environments. The CCBG is a group that brings together users from a wide range of technologies, markets and territories, working together to further develop a global and unique standard for broadband mobile radio communications. At the same time, the group that develops TETRA within ETSI changed the previously existing name Technical Committee-TC to the new name TETRA and Developed Mobile Radio Communications for Crisis Situations-TCCE (TETRA and Critical Communications Evolution), which is still today valid. It turned out that that moment was actually a crossroads both for the TETRA standard itself and for TCCA. Figure 3 shows the course of the complete development of TETRA, from the initial agreement of the manufacturers in 1989 for the development and production of MDTRS to the mentioned moment of the creation of TCCA in November 2011.

However, nowadays there are still such PMR holders for whom, due to the narrow frequency spectrum assigned to them, broadband transmission of radio information is simply uneconomical or completely unacceptable. In this regard, regardless of the fact that TETRA is, realistically speaking, the first and most sought-after technology of today for such purposes, there is no doubt that it, as such, will meet strong opposition and competition in the future. That is why the TETRA standard still needs a strong and focused association which will successfully defend the interests of suppliers of network infrastructure equipment, mobile radio terminals, peripherals, and software applications in the market. On the other hand, it has been proven many times that TETRA works very successfully and reliably with other mobile radio communications networks (which operate according to different standards and technologies), and especially with the networks of public mobile radio communications operators. The possibility, that is, the permission for the modern 4G LTE network (Long Term Evolution), which is primarily intended for very fast packet data transmission (Gospić et al, 2010), in terms of complementarity, to coincide with TETRA was obtained ten years ago, and this was done much earlier for the North American standard P25. 


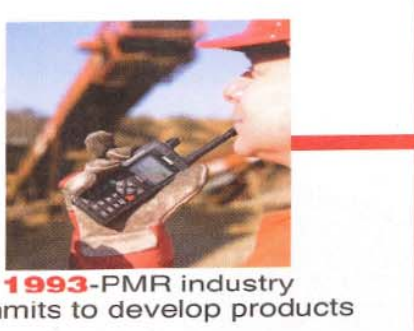

commits to develop products
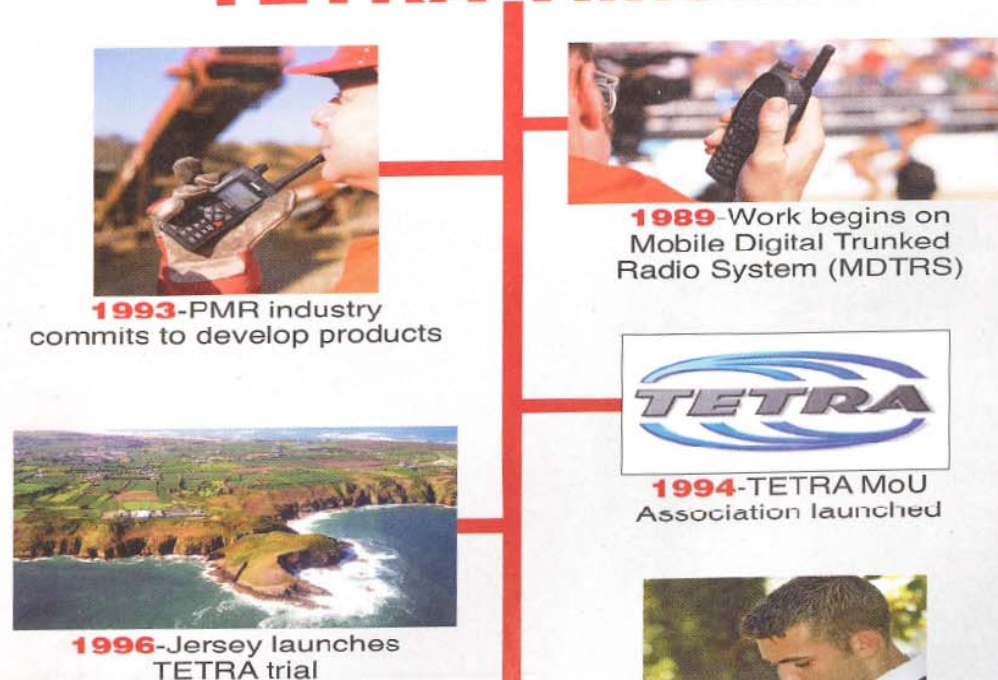

Mobile Digital Trunked
Radio System (MDTRS)
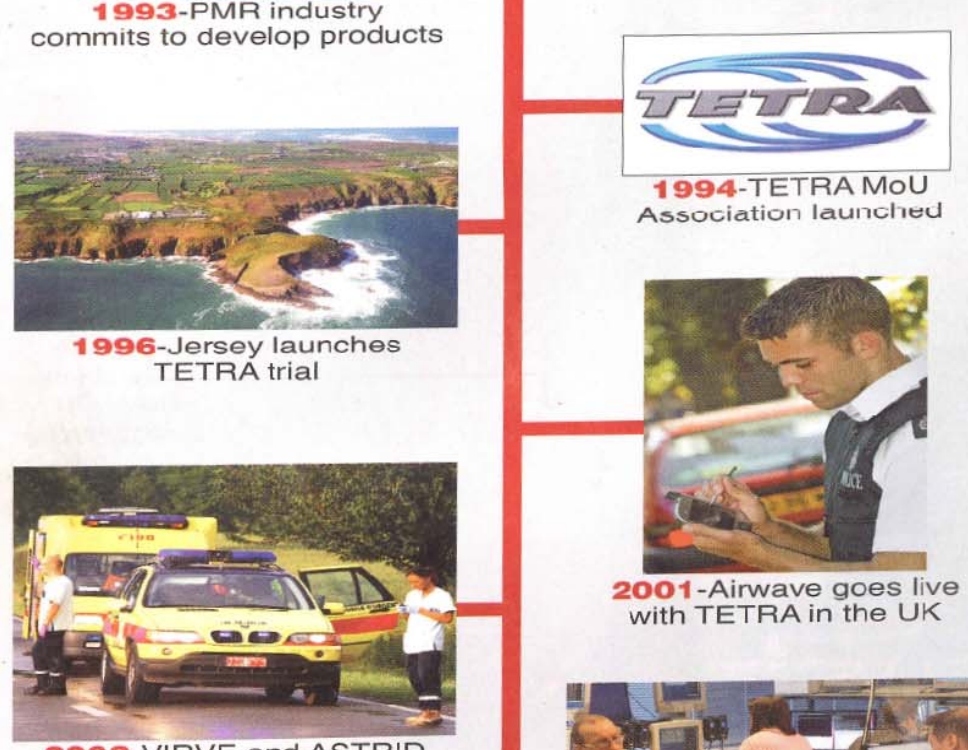

2002-VIRVE and ASTRID launch networks in Finland and Belgium respectively
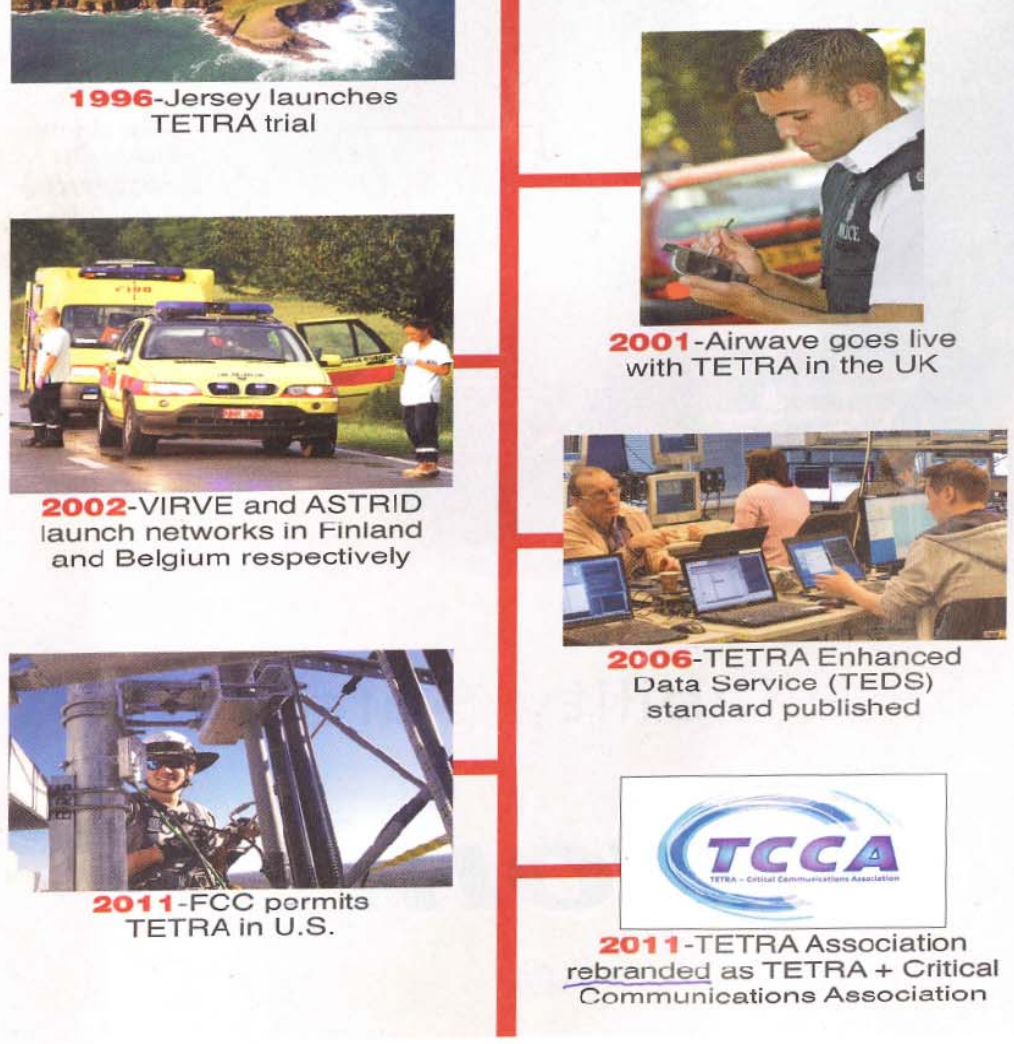

Figure 3 - Overview of the TETRA development line (Swan, 2015)

Puc. 3 - Обзор линии развития TETRA (Swan, 2015)

Слика 3 - Приказ линије развоја TETRA (Swan, 2015) 
Now the only question is whether, at some point, the mentioned modern 4G LTE network (or the most modern and "controversial" 5G Global System Mobile-GSM network), which normally supports simultaneous voice transmission and very fast data transmission for public mobile radio communications (in critical situations as well), will become a direct competitor to TETRA in terms of functional user support? What this chapter will look like in the book of TETRA's historical development cannot yet be predicted with certainty, but it seems to be already anticipated that, with certain limitations, TETRA will successfully cope with such an opportunity and competition of this kind. (Swan, 2015)

\section{The basis of TETRA technology}

Today, TETRA is the most modern open standard for Functional digital trunking systems of mobile radio communications which consists of a series of specifications developed by the European Institute of Telecommunications Standards-ETSI (Svrzić \& Ćosović, 2002b). Basically, TETRA is intended as a standard for owners and users of Functional digital mobile trunking radio communication systems in the field of national and public security (police, gendarmerie, army, fire service, ambulance service), large companies engaged in energy distribution (electricity, oil and gas industry), transport companies (airports, railways, ports, road transport), service providers and, finally, public mobile telephony operators with integrated data transmission. As a complete digital system of mobile trunking radio connections, modern TETRA systems are characterized not only by exceptional efficiency in using available frequency spectrum but also by high quality processing, transmission and switching of speech and data signals, pronounced security of system access and information transmission with crypto protection services and modes of operation, and a wide range of basic and ancillary services (ETSI, 2009). All this contributes to the fact that these mobile radio communication systems are highly professional, efficient and flexible for different applications, enabling solid coexistence with still existing analog trunking and conventional functional and public mobile radio communication systems, and that today they are, as such, the most promising and most interesting for owners and users of functional communication systems, and even (in some circumstances) for network operators and providers of public mobile telephony services (Ovchinnikov et al, 2000), (Svrzić \& Ćosović, 2002a, 2002b).

Mobile radio communication trunking systems, analogue and digital, are in fact UHF mobile radio systems that perform automatic switching of 
available Communication Radio Channels (CCh) of Base Radio Stations (BS), for interconnection of mobile participants, as well as for connection of mobile participants with other participants. One of these CCs must be used as a Management Channel (MCh). Through this channel, calls are registered by mobile and other participants, status messages are transmitted and the order of connection requests is assigned. Namely, as soon as the request for establishing a connection arrives, one of the free $\mathrm{CCh}$ (channels from the capacity of the respective BS, in whose service zone the participant who sent the request for establishing a connection is) is assigned to participants in connection with exclusive use, for mutual communication. In cases when, during the established connection, new calls for establishing connections via the same BS arrive on the system, they are assigned the remaining, not occupied, CCh for the connection, until the full utilization of the Communication Channels capacity on the respective BS. If all channels are busy, new connection requests are queued (these requests are queued), and as soon as one of the busy channels is released, the system assigns it to the first participant on the queue. This means that in the trunking system of mobile-radio connections, the call for connection is sent only once because, in case of impossibility for current connection, that call will be placed on the waiting list and will be processed later in the order and priority that the participant has (Ovchinnikov et al, 2000), (Svrzić \& Ćosović, 2002a). Figure 4 block diagram shows the general principle of the organization of digital trunking system of mobile radio communications with the TETRA 1 standard (Rohde \& Schwartz, 1999a), (ETSI, 2019).

Trunking mobile radio communication systems belong to the class of mobile radio communication systems which are, above all, oriented to the formation of various functional and corporate radio networks, which provide for the active application of mobile users in separate speech groups, formed for some permanent or temporary assignment. It is clear that such systems are mainly used by the police, specialized social security and protection services, companies engaged in land and air transport, large producers and distributors of all types of energy (oil, gas, electricity, etc.) in different countries, as well as the military, in order to provide functional connections between mobile radio participants, mobile radio participants and fixed radio participants, as well as mobile radio participants with participants of public telephone-PSTN and ISDN and functional telephone networks-PABX (Ovchinnikov et al, 2000), (Svrzić \& Ćosović, 2002a), (ETSI, 2004). In connection with the above, Figure 5 shows different possibilities for connecting to a TETRA network. 


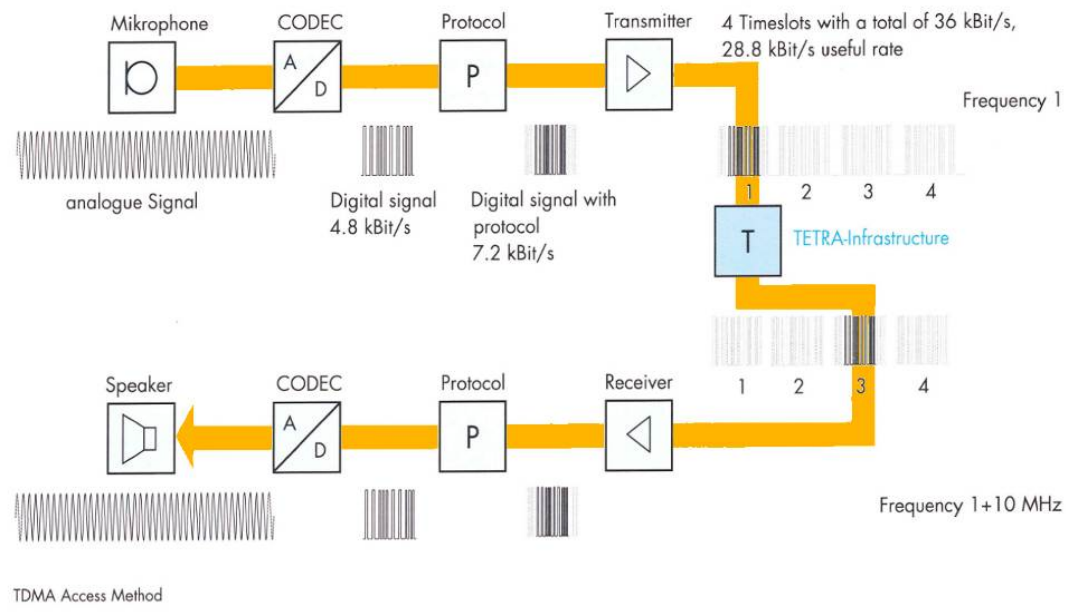

Figure 4 - Block diagram and the general principle of organizing the digital trunking system of mobile radio links TETRA 1 (Rohde \& Schwartz, 1999a)

Pис. 4 - Блок-схема и общий принцип организации цифровой транкинговой системы мобильной радиосвязи TETRA 1 (Rohde \& Schwartz, 1999a)

Слика 4 - Блок-шема и општи принцип организовања дигиталног транкинг система мобилних радио-веза TETRA 1 (Rohde \& Schwartz, 1999a)

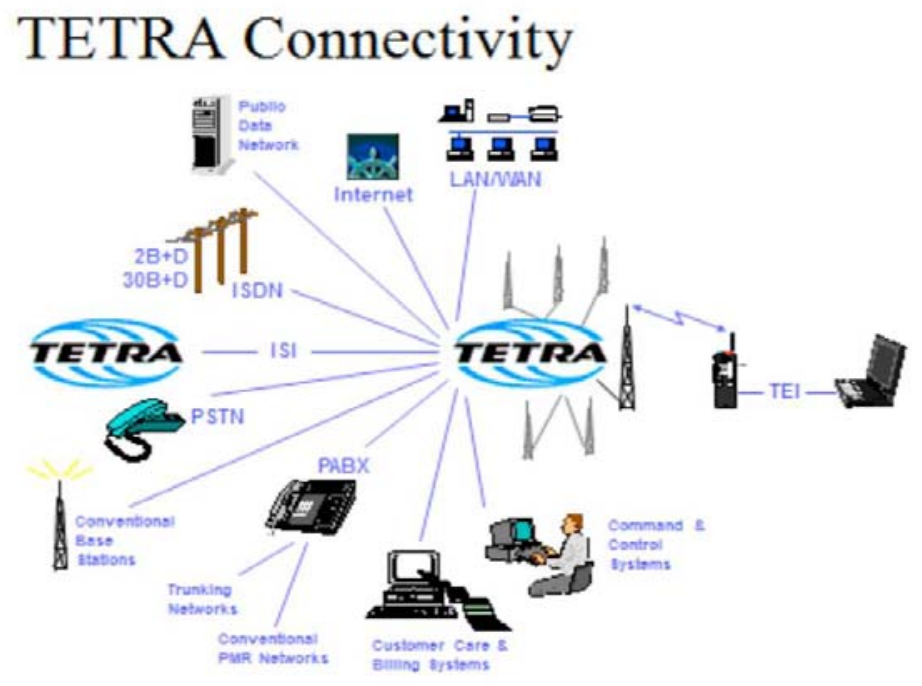

Figure 5 - Overview of different connectivity options in TETRA networks (ETSI, 2004)

Puc. 5 - Обзор различных вариантов подключения к сети TETRA (ETSI, 2004) Слика 5 - Приказ различитих могућности за повезивање у TETRA мреже (ETSI, 2004) 


\section{Second generation of TETRA, data transmission development, improved interoperability and penetration on the North American market}

\section{Improving standards}

Fewer than five years passed since its inception, and back in 1999, the members of the ETSI TETRA project, which included both users and manufacturers within the then TETRA Technical Committee (TC) and the TETRA Association (TA), recognized the need for the necessary generational advancement of the existing standard, tentatively called TETRA 1, in several areas. Although the number of these areas was initially wide, significant developments in the telecommunications industry, combined with changes in market needs, led to ETSI deciding in September 2000 to start activities to improve the existing standard towards the second-generation TETRA. As a result of these activities, a document was published at the end of 2005 defining the areas, services and characteristics of the TETRA 1 standard envisaged for treatment and improvements through the new TETRA 2 standard (Swan, 2015). Thus, according to the new TETRA 2 standard, special attention is paid to achieving improvements in the following areas:

- increase connection range in TMO mode,

- use of AMR (Adaptive Multiple Rate) voice CODEC,

- use of mixed excitation, with line prediction, excited voice CODEC MELPe (Mix Exitation Line Prediction), and

- introduction of an advanced part of the High-Speed Data standard, called TETRA Enhanced Data Service-TEDS. (Nouri, 2016)

Increasing the connection range in TMO mode was the need for the innovated TETRA to be able to operate outside the existing $58 \mathrm{~km}$ range limits, which was a limitation imposed by the TDMA network infrastructure, related to synchronization transmission. This was primarily a requirement of the user organization (system owner) to enable efficient air-ground-air (A-G-A) communications, while working on TMO in the relevant network infrastructure. Therefore, the necessary modifications of the "burst" on both links ("up-link" and "down-link") were defined, as well as the shortening of the time for their realization, thus making the TMO connection range for AGA communications applications in network increase to $83 \mathrm{~km}$. Of course, since the DMO mode in the TETRA network has no connection range limitation (in terms of TDMA infrastructure), because the synchronization in this mode is realized at 
the beginning of each of transmission sessions, it was not a topic in this case when innovating the standard.

The use of AMR's multi-purpose adaptive voice CODEC, which only works with an $A / D$ conversion rate of $4.75 \mathrm{~kb} / \mathrm{s}$, was stopped by TC at the very beginning because the completion of innovations for the Al radio interface was delayed, and to which AMR actually needs to adapt. The explanation was to wait until a real market need for its implementation is clearly established.

The use of mixed excitation, with linear prediction, of the induced voice CODEC MELPe, which is standardized by NATO (called STANAG 4591) for use in their military communications, was introduced to improve the TETRA standard primarily due to the low bit rate for $A / D$ conversion of only $2,400 \mathrm{~b} / \mathrm{s}$, followed by high resistance to high levels background noise and due to acceptable voice encoding / decoding performance. Since it was clear from the very beginning that there is a great suitability for the use of TETRA in military communications, TC made a study of the technical feasibility of applying voice CODEC MELPe to TETRA, from the framework that resulted in:

- possibility of working with government systems and other state institutions (without working in tandem),

- possibility of suppressing high levels of noise and noise from the environment,

- possibility of enhanced RF coverage using spare bits available for direct error correction of FEC (forward correction) in transmitted information, and

- possibility of integrated $(V+D)$ use of spare bits available for Data.

However, when emphasizing all the above benefits, it should be noted that the very technique of implementing voice CODEC MELPe in TETRA contributes to increasing the delay in voice transmission in "end to end" communications, which is understandably a disadvantage. Therefore, the completion of the TETRA 2 standard with voice CODEC $M E L P e$ depended on the outcome of the relationship between these benefits and on the increase of the cost of its implementation, compared to the costs that existed until then using the current ACELP voice CODEC. (Nouri, 2016)

The introduction of an advanced standard for High-Speed Data transmission-TEDS had its prehistory, since at the beginning, in fact, two different ways of developing data transmission according to the TETRA 2 standard were planned (and took place): 
1. TETRA Advancet Packet Service - TAPS, which is based on the evolution of GRPS/EDGE standards, and thus was focused mainly on the PAMR market (for public communications), and

2. TETRA Enhanced Data Service - TEDS, which implied a slightly different appearance of the standard, in terms of data transfer speed, and was aimed at the entire TETRA market (across all sectors). In addition, it envisaged full compatibility with TETRA $V+D(T E T R A 1)$ and easy migration of equipment from TETRA $V+D$ to TEDS, as well as flexible use of the existing frequency spectrum allocated for use in PMR of different holders.

The decision on that issue was postponed for some time, but it was finally made, after the consensus on the WG4 EPT working group reached on July 4,2002 . The concept of TEDS won, as a route preferred by the world's six largest manufacturers of TETRA equipment (with five different technologies) and by most of the functional users of PMR. However, the new standard was not reached easily, but through painstaking debates over the choice of one of these initially offeredproposed options of 5 technologies (6 different manufacturers). Therefore, there were many failed attempts to reach a consensus on this issue, so that the development of the standard lasted for the next 4 years, so the amended TETRA 2 standard was not officially published until 2006 (Swan, 2015), (Nouri, 2016), (Dewaele, 2016).

Since then, until today, several significant improvements have been made within the new TETRA 2 standard, including: High Speed Data (HSD) and the selection and standardization of additional CODECs for speech digitization. In addition, the following were realized: the evolution of the TETRA SIM card, achieving interoperability, and even roaming, between TETRA 2 and public GSM, as well as the transition from 2.5G / $3 G$ network, while maintaining broad compatibility with the first generation of all types of TETRA 1 devices and the full integration of their features into the new generation of TETRA 2 devices (Swan, 2015), (Nouri, 2016).

In this regard, it should be noted that all these improvements did not immediately and simultaneously come to life in practice, but it was crucial to recognize in time the need for the standard to evolve, especially in terms of increasing data rates (over 10 times). Of course, such an evolution could not go hand in hand with other PAMRs, from GSM to GPRS, EDGE, UMTS / 3G, all the way to the state-of-the-art super-fast LTE data transmission system. For example, some well-versed in this technology claim that the emergence of a new model for HSD, i.e. TEDS, 
in the historical development of the TETRA standard, was actually its new, second beginning. Indeed, for such a (until then) successful standard, the speed with which potential users-owners of the PMR system recognized all the qualities of TEDS was initially disappointing. This is confirmed by the fact that immediately after its appearance, at the beginning of December 2006, TEDS was accepted and implemented only in the national network of mobile radio communications in Norway, called "NODNET", and for the needs of public security of that country. Only a little later, during 2010, the innovated TEDS standard began to be applied in other national TETRA networks. Specifically, it was within the Finnish TETRA network of operators "VIRVE", in which it was first tested in the same year, and then the operational implementation of TETRA TEDS began. (Swan, 2015)

\section{Development of data transmission applications}

When it comes to the domain of data transmission application, the recent history of the standard shows that TETRA is primarily a successful standard in the domain of data transmission for Short Message and Status Messaging Systems. Namely, it is known that there is a whole special "industry" that writes software applications intended for user radio terminals and the operator of the TETRA terminal. These applications enable efficient machine-machine transfer of various important information and Data from the field to the control centers in real time In particular, the sector of companies engaged in the transport of people and goods has realized that TETRA is, in this respect, very efficient and highly efficient, for example, in the subways of large, densely populated world capitals such as Hong Kong, Singapore and London. This was also understood by large bus transport systems, such as the one in Barcelona. Finally, this was realized very early on by companies operating a number of large airports around the world.

Wih the evolution of the displays of the participating mobile radio terminals, with more and more options, as well as with the evolution of the processing power of terminals themselves, the developers are constantly making better and more complex software applications for them. In addition, for certain interest groups of users, the use of the Peripheral Equipment Interface-PEI has been introduced into the common standard, enabling the functioning of a wide range of supported peripherals, as well as the monitoring and control of SCADA process management data reception where there is no requirement for special information protection and where a relatively low data rate is sufficient. This occurs, for example, in mining, in oil and gas pipelines, or in the 
distribution of electricity and water. The location information, where the terminal user is located, is by far the most used TETRA application, directly related to Data transmission, which is why most TETRA terminals are equipped with the GPS (Global Position System). Of course, the transmission of the mentioned location information is one of the main features of TETRA, whether it is a systematic monitoring or updating of MS locations in the "Home Register", precise determination of the location of the operator in a critical situation, or determination of the terminal location where the alarm is activated for some reason. Finally, GPS data also enables local distribution of accurate time, as well as accurate time stamping of status and short text messages, thus supporting one of the newer features of TETRA on the market: the production of high-resolution photographs with accurate time stamping. This capability makes the TETRA terminal more than a communication device. The photographs taken in this way are stored and stored at the terminal itself, in safe and isolated conditions, and can be switched from the built-in memory card to another medium if needed (Swan, 2015).

However, the first years of TETRA's existence showed why in the beginning it was necessary to very carefully advertise the possibilities of the standard in the field of application of data transmission. Namely, although the claims that TETRA 1 can successfully support a data transfer rate of $28.8 \mathrm{~kb} / \mathrm{s}$ - at a time when public GSM could support a transfer rate of only $9.6 \mathrm{~kb} / \mathrm{s}$ - were incorporated into many business offers, it turned out that in practice it was still unsustainable for some time. Indeed, the first packet data transmissions with a base speed of 7.2 $\mathrm{kb} / \mathrm{s}$, which used one "time slot", i.e. one Communication Channel, from the basic TETRA 1 TDM frame, were not operational until 2000.

Higher-speed packet transmissions (14.4 - $28.8 \mathrm{kbit} / \mathrm{sec})$, i.e. those that use multiple time slots (2.3 or all 4), became operational only in 2005 (Swan, 2015). Of course, with the improvement of standards with the advent of TEDS, user data rates have increased many times, so they vary from $30 \mathrm{~kb} / \mathrm{s}$ (for $25 \mathrm{kHz}$ wide $R F$ radio channel) to a maximum of $500 \mathrm{~kb} / \mathrm{s}$ (for $150 \mathrm{kHz}$ wide RF radio channel). (Nouri, 2016)

\section{Improving interoperability}

Interoperability and its positive certification tests are the essence of any open standard. In the TETRA standard, this is obtained through the interoperability certification regime, which is a strictly controlled process performed by an independent certification body. This process was defined by the TETRA MoU Association, and the first certificates were obtained in 1999 for TETRA products of four large manufacturing 
companies, which are still key in the market of TETRA technology: Marconi (now SELEX), Motorola (now Motorola Solutions), Nokia (now Airbus Defence and Space) and SIMOCO (former Philips Telecom). Since then, more than 750 interoperability certificates have been issued, but each has a different combination of TETRA radio network infrastructure and radio terminals themselves. (Swan, 2015)

\section{TETRA in North America as well}

How the new TETRA 2 standard managed to enter the North American PMR market is an interesting story. With much drama, the Federal Communications Commission-FCC allowed TETRA to be implemented in the United States no sooner than April 2011, except for some PMR users in the public security sector, whose assigned spectrum was then under reconfiguration. When the FCC completed the final change in the frequency spectrum in September 2012, it issued licenses for the unrestricted use of TETRA technology and for public safety mobile radio communications in critical situations for the parts of the spectrum 450-470 MHz and 809-824/854-869 MHz. After that, the following situation prevailed in the North American PMR market: "TETRA has clearly become a valuable option for all those owners of functional mobile radio systems (licensees for the use of frequencies), whose basic requirements are that such systems must have high spectral efficiency. In addition, it has become clear that TETRA offers much more effective protection from of neighboring radio channels, compared to all other PMR systems currently operating in LRM bands."

In many ways, the opportune moment for TETRA standards to enter the North American market proved to be a very good opportunity for the already existing set of finished products (mobile terminals and infrastructure devices), together with their accompanying and peripheral equipment, as well as for a large number of already proven applications which, as such, could all together be immediately offered to the market. This further proved to be quite true, because some large TETRA systems have been implemented throughout the United States today, primarily in the segment of transport and services, and it can be said with certainty that there will be many more of them in other organizational and government structures in the future. (Swan, 2015) 


\section{Data transmission according to the TETRA 2 standard}

When it was decided within ETSI to improve the TETRA 1 standard, especially in the framework of the TETRA data transmission part, the following reasons were primarily specified and taken into account:

- due to very rapid changes in the world of telecommunications, it was necessary to provide assistance to the entire TETRA community in the development of broadband and multimedia services;

- the introduction of an innovated-more modern standard actually extends the life cycle of TETRA technology as a whole;

- by introducing an innovated standard, the existing users - owners of TETRA $V+D$ networks (TETRA 1) are supported for the smooth implementation of "up-grade" on these networks;

- the introduction of the innovated standard enables uninterrupted operation of TETRA with new public mobile telephony networks $(2.5 \mathrm{G} / 3 \mathrm{G})$;

- the new standard actually ensures the future of the existing and security of new investments to TETRA system holders; and

- by applying this standard, which includes HSD, many benefits of new technologies are realized.

After that, the Commission No. 28 of EPT TETRA adopted a revised terms of reference for the innovated TETRA 2 standard, which included the implementation of the already partially mentioned requirements:

- support for packet data transmission at higher speeds, which are up to 10 times higher than that allowed by the TETRA 1 standard (TETRA $V+D$ and TETRA PDO);

- selection and standardization of additional-new CODECs, for even more effective realization of digitalization of speech signals;

- new improvements in the part of the standard related to the TETRA radio interface;

- improving interoperability and enabling roaming with GSM and 2.5G/3G networks of public mobile radio links;

- development of the TETRA SIM card into a new, TETRA U-SIM card;

- spatial expansion of operational operability (connection range) in TETRA networks, with minimum requirements for the introduction of new BS or for a new expansion of the spectrum; and

- enabling full compatibility and integration of technologies between the innovated TETRA 2 and the existing TETRA 1 standard and the necessary migration. (Nouri, 2016) 
For the realization of the thus defined TETRA 2 standard, as stated earlier, out of the two proposed different paths of development (two different concepts called TAPS and TEDS), the concept of TEDS prevailed, which was based on the initial solutions of 5 different technologies of six manufacturing companies. According to the adopted concept, in practice, new-heterogeneous TETRA structures were created, whose integration into the system of public radio networks of mobile telephony $3 G$ was realized in the way shown in Figure 6.

Shortly after the release of the innovated TETRA 2 standard, several different user requirements were reconciled, which slowly led to better adaptation to changing market conditions, as well as to resolving some of the problems that had led to "conflicts" in the earlier standard. Therefore, the TETRA 2 User Workshop (together with the WG1 EPT) was able to achieve the following practical results:

- most data transmission applications in previously built TETRA 1 systems could now be raised to the level of speeds of $50-80 \mathrm{~kb} / \mathrm{s}$;

- at the edges of the BS coverage zones, a data transfer rate of at least $50 \mathrm{~kb} / \mathrm{s}$ was now provided;

- it is possible to develop adaptive technologies and technologies for high data transmission speeds in order to ensure the investments of the system owner in the long run;

- integrated high-speed voice and data transmission is achieved, where (if required) speech transmission must be given priority;

- it was agreed that mobile handheld terminals will be made with a power of $1 \mathrm{~W}$ while mobile transport devices will have a power of $3 \mathrm{~W}$; and

- it was agreed that all technological processes be revised in accordance with the above practical results. (Nouri, 2016)

In addition to the above compromise reached between 6 global equipment manufacturers, WG4 EPT has raised some other unresolved issues from the standard, namely:

- resolving all remaining unresolved issues in the domain of the physical layer of the protocol;

- resolving the issue of the highest network layer protocol; and

- resolving the issue of adaptive use of resource systems.

Of course, care was taken to use, as much as possible, the existing quality solutions from the TETRA $V+D$ specification, in order to ensure the necessary compatibility between the earlier TETRA 1 and the modernized version of the TETRA 2 standard (for example: within TEDS, a solution is adopted for the use of the Common Management Channel, 
which is identical to the solution of the Management Channel at TETRA V + D). (Nouri, 2016)

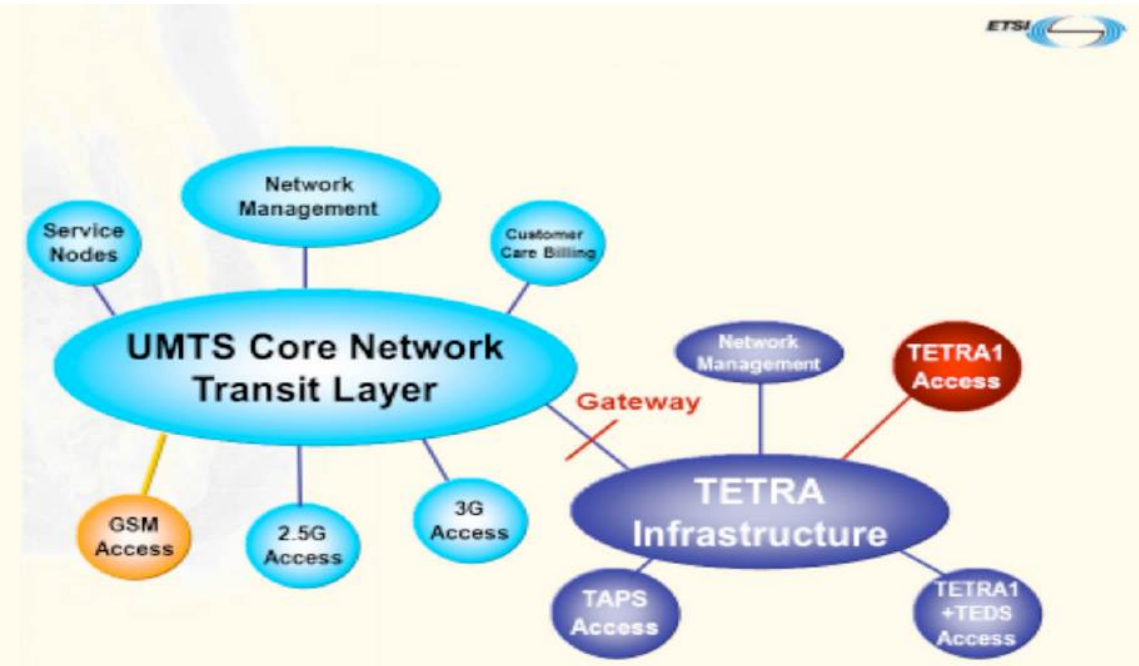

Figure 6 - Presentation of the formation of heterogeneous TETRA structure in the era of $3 G$ network (Nouri, 2016)

Puc. 6 - Презентация фрормирования гетерогенной структуры TETRA в эпоху сетей $3 G$ (Nouri, 2016)

Слика 6 - Приказ настанка хетерогене TETRA структуре у ери $3 G$ мреже (Nouri, 2016)

\section{Selected parameters from the framework of TEDS} technology

TEDS is part of the new TETRA 2 high-speed packet data standard, which uses different $R F$ radio channel widths for different data rates, with flexible use of the assigned frequency spectrum in the PMR of different system holders. This TETRA 2 standard is fully compatible with TETRA 1 , and provides the ability to easily migrate from TETRA $V+D$ to TEDS. It is optimized for efficient use of the part of the radio frequency spectrum assigned for use to the holders of functional mobile radio communication systems and is designed for all applications from the TETRA market segment. TEDS uses a platform with several radio frequency carriers on which TDMA is organized. In doing so, an adaptive selection of several offered types and types of modulation and coding was adopted, all in accordance with the current conditions for propagation prevailing in the air and (of course) in accordance with the possible desired data signal transmission rate. (Nouri, 2016) 
Regarding data signal modulation, within TEDS, 5 types were selected from the framework of 2 types of digital modulations (QAM and DPSK), as follows:

- 4QAM, to achieve stable and efficient links, even on the edges of $B S$ zones, where radio coverage is not of the highest quality;

-16QAM, for medium data transfer;

-64QAM, for high speed data transmission;

- $\pi / 4$ DQPSK, for the Official Control Channel for TETRA $V+D$ and TEDS; and

- $\pi / 8$ D8PSK, at the beginning of the migration of previously built TETRA 1 systems into new systems (or parts of systems) with TEDS, and when a modest increase in data transfer speed is achieved.

Regarding channel coding, it should be said that within TEDS, optimized coding in the channel is applied, which is in accordance with the recommendation of STF 179 (Specialist Task Forces). In addition, TEDS defines 4 different frequency range widths around the radio carrier ( $R F$ radio channels), which is directly related to the required data rate, namely:

- $25 \mathrm{kHz}$,

- $50 \mathrm{kHz}$,

- $100 \mathrm{kHz}$, and

- 150 kHz. (Nouri, 2016).

Table 1 shows the ratio of possible-estimated packet data rates in (kb/s), depending on the selected width of the RF radio channel, and with a strictly defined application of the type and type of signal modulation, on the connecting path at the improved "down-link". From the presented Table, it follows that user data signal flow rates in the range of 10-500 $\mathrm{kb} / \mathrm{s}$ can be expected by applying adaptive selection of type and type of modulation, adjusted RF channel width and realization of coding according to currently existing conditions for radio wave propagation.

These estimates of numerical values of flow rates are valid for the moments when the permission for synchronization and transmission of "pilot symbol" (according to the system protocol) has been given, and after the realized channel coding, and transmission of headers and functions of lower (channel) system protocol level. (Nouri, 2016) 
Table 1 - Ratio of possible-estimated packet data rates (in $\mathrm{kb} / \mathrm{s}$ ), depending on the selected width of the RF radio channel and the type of signal modulation Таблица 1 - Соотношение возможных расчетных скоростей передачи пакета данных (в кБ / с), в зависимости от выбранной ширины РЧ радиоканала и применяемого вида модуляции сигнала

Табела 1 - Однос могућих-процењених брзина пакетског преноса података (у $\mathrm{kb} / \mathrm{s})$, у зависности од одабране ширине РФ радио-канала и примењеног типа модулације сигнала

\begin{tabular}{|c|c|c|c|c|}
\hline \multirow{2}{*}{$\begin{array}{c}\text { TYPE OF } \\
\text { MODULATION }\end{array}$} & \multicolumn{4}{|c|}{ Type of channel (frequency spectrum width) } \\
\cline { 2 - 5 } & $25 \mathrm{kHz}$ & $50 \mathrm{kHz}$ & $100 \mathrm{kHz}$ & $150 \mathrm{kHz}$ \\
\hline$\pi / 4-D Q P S K$ & $15.6 \mathrm{~kb} / \mathrm{s}$ & & & \\
\hline$\pi / 4-D 8 P S K$ & $24.3 \mathrm{~kb} / \mathrm{s}$ & & & \\
\hline $4-Q A M$ & $11 \mathrm{~kb} / \mathrm{s}$ & $27 \mathrm{~kb} / \mathrm{s}$ & $58 \mathrm{~kb} / \mathrm{s}$ & $90 \mathrm{~kb} / \mathrm{s}$ \\
\hline $16-Q A M$ & $22 \mathrm{~kb} / \mathrm{s}$ & $54 \mathrm{~kb} / \mathrm{s}$ & $116 \mathrm{~kb} / \mathrm{s}$ & $179 \mathrm{~kb} / \mathrm{s}$ \\
\hline $64-Q A M(r=1 / 2)$ & $33 \mathrm{~kb} / \mathrm{s}$ & $80 \mathrm{~kb} / \mathrm{s}$ & $175 \mathrm{~kb} / \mathrm{s}$ & $269 \mathrm{~kb} / \mathrm{s}$ \\
\hline $64-Q A M(r=2 / 3)$ & $44 \mathrm{~kb} / \mathrm{s}$ & $107 \mathrm{~kb} / \mathrm{s}$ & $233 \mathrm{~kb} / \mathrm{s}$ & $359 \mathrm{~kb} / \mathrm{s}$ \\
\hline $64-Q A M(r=1)$ & $66 \mathrm{~kb} / \mathrm{s}$ & $160 \mathrm{~kb} / \mathrm{s}$ & $249 \mathrm{~kb} / \mathrm{s}$ & $538 \mathrm{~kb} / \mathrm{s}$ \\
\hline
\end{tabular}

NOTE: All channels use 4 slots

The flow rate estimation, in the enhanced link, is actually based on the use of the MAC-U-BLCK PDU sub-levels of the system protocol, for "up-link", and the MAC-D-BLCK PDU, for "down-link", without permission for merging multiple "slots". The PILOT SYMBOL method, within TEDS, is used to assess the quality of data transmission according to the displayed flow rates, through some of the thus formed Communication channels with permission to use all 4 "time slots "on one radio carrier. Such estimates of flow rates and transmission quality enable TEDS to transmit up to 8 multimedia applications with defined QoS for real-time transmission class applications, such as voice, image and video transmission, telemetry signal transmission and others, and all with prescribed characteristics for the selection of flow rate, delay, priority and reliability.

Due to the fact that the new standard maximizes the possibility of reusing the stacks of the TETRA 1 protocol and its TDMA infrastructure, in practice the processes of evolution and migration from TETRA 1 to TETRA 2 have been greatly facilitated, i.e. to the TEDS standard. In this way, support is given for the smooth operation of "isolated radio cells" within the heterogeneous network infrastructure, which will occur when certain parts based on TEDS are implemented in the network. In addition, it also means that within the resulting heterogeneous infrastructure "TETRA 1-TEDS-TERA1" networks normally continue to use existing TETRA $1 \mathrm{BS}$, as there is no systemic conditionality for the 
procurement of new ones. As for the essential principle of operation, as mentioned, the concept of TDMA has been retained, but now the duration of the "time slot" in the basic TEDS TDM frame is different, depending on the selected bandwidth (i.e. the selected baud rate data). Thus, the duration of the basic time slot (i.e. the Communication chennel) is now:

- $14.167 \mathrm{~ms}$, when using $25 \mathrm{kHz}$ (or possibly $50 \mathrm{kHz}$ ) radio channel width on the selected radio frequency carrier, where a low level of digital signal modulation speed is realized; and

- $7.08 \mathrm{~ms}$, when using $100 \mathrm{kHz}$ (or possibly $150 \mathrm{kHz}$ ) radio channel width on the selected radio frequency carrier, achieving a high level of digital signal modulation speed. (Nouri, 2016)

Within the innovated standard, it has also been adopted that in adaptively selected quaternary digital signal amplitude modulation (i.e., XQAM type), each QAM carrier consists of several QAM subcarriers, around which the basic frequency bands of the $3.125 \mathrm{kHz}$ speech signal are formed. Thus, for example, in a radio channe/ with a width of $25 \mathrm{kHz}$, a total of 8 QAM subcarriers are realized, each with its basic frequency band of $3.125 \mathrm{kHz}$. In radio channels with a width of 50, 100 and 150 $\mathrm{kHz}$, a relatively larger number of QAM subcarriers is realized, so data transfer speeds from 30 to $350 \mathrm{~kb} / \mathrm{s}$ can be realized in reality. Finally, in this standard it is adopted and realized that the higher levels of the system protocol from the framework of TETRA $V+D$ are fully compatible with the system protocol TEDS.

As for the support provided by the STF, part of ETSI, for the implementation of the TEDS standard, it consists of the following contributions:

- optimized coding in the radio channel is defined and carrier repetition is enabled;

- an adapted TETRA 2-TEDS protocol has been defined, which refers to higher levels of the protocol - without a physical layer;

- the adaptive TEDS (Link Control) Control Channel has been defined; and

- the use of multimedia services is defined.

In this way, the innovated TETRA standard with TEDS created the conditions which enabled its implementation in the field (in practical mobile radio trunking systems) to achieve fully completed results of providing quality advanced services for the integration of voice 
transmission and fast data transmission ("voice" and "data" services), as follows:

- within the mobile radio transmission (group, individual, priority calls and emergency call according to TMO, as well as realization of DMO),

- within mobile telephony (full duplex voice transmission), and

- within high-speed mobile data transmission (transmission of SM and SDTS messages, packet-switched data transmission, circuitswitched data transmission). (Nouri, 2016)

Of course, it would be correct to present the existing limitations of TEDS application in practice, especially in the part of the dependence of the desired data rate on the selected width of the Communication Radio Channel and the distance of the mobile radio terminal from BS, which is systematized in the (Dewaele, 2016).

\section{Conclusion}

Due to a very pronounced quality of service it offers, the introduction of a single frequency plan, the possibility of organizing a large number of Communication-Traffic and Management channels, as well as the introduction of high-level communications protection, and thus its great prospects, the standard for Digital Tranning Mobile Radio Communications has gained high references in just a few years of its existence. After 25 years of its existence, it is safe to say that the TETRA standard has become the most accepted in the world, not only for functional, but partly for public mobile radio communication systems (Svrzić \& Ćosović, 2002b). In the development and implementation of this standard so far in a large number of small and large digital trunking networks of mobile radio communications, it turned out that, compared to other systems of digital trunking mobile radio communications, it is the most suitable and very much needed for application in the Sector of public safety and security, the Transport Sector, the Commercial Services Sector, the Industry, Electricity and Mining Sector, the Government Organizations Sector and local governments and, finally, the military (Svrzić \& Ćosović, 2002a, 2002b). Therefore, the total number of TETRA terminals operated to date has exceeded the number of 6 million sets, expressing their permanent annual growth of $8 \%$ (Swan, 2015).

In this regard, it is important to remember that (based on the Memorandum of Cooperation and Understanding of the MoU from 1994) TETRA as an open standard was first accepted, and to this day continuously supported, by most of the world's leading manufacturers of Analog trunking systems mobile radio communication. Since then, the 
number of manufacturers-supporters of TETRA has been constantly increasing from year to year, so that the list of manufacturers of equipment for mobile radio communication systems according to the TETRA standard is very long today.

In fact, the real expansion of the TETRA standard occurred in early 1999, when Europe's largest public mobile radio operator Dolphin Telecom Plc decided to start building a National public TETRA mobile radio system in the UK and France, and then very soon afterwards in Germany and Belgium. At the First World Annual TETRA Congress held in Berlin in 1998, the marketing director of that operator, Mr. Mark Riley, stated that the infrastructure of an impressive number of 655 Base Radio Stations had been planned for the National TETRA system of public mobile radio communications in Great Britain. According to the project, they were supposed to provide coverage of $95 \%$ of the total population in Great Britain by the end of 2001. A total of about 200,000 terminal devices $(10,000$ mobile radios for installation in vehicles and 190,000 portable radio devices) had been ordered for work in the networks of that system. Unfortunately, due to business failures in general (not related to TETRA networks) this large European public mobile operator of radio communications had to go bankrupt, so all its built TETRA networks were excluded from operational work by the end of 2002 (Swan, 2015).

At that time, many owners of functional systems also took steps to replace their existing systems of Analog trunking of mobile radio connections, that is, to build new modern systems of Digital mobile radio communications according to the TETRA standard. Today, the following realized projects are considered to be the main achievements of TETRA application in Functional systems of mobile radio communications: National Network "PSRCP/AIRWARE" in Great Britain, which was put into operation in 2001, then National Network "VIRVE" in Finland, whose operational use began in 2002, followed by the National Network "ASTRID" in Belgium, put into operation by 2002, the National Network "C2000" in the Netherlands, established in 2004 and, most recently, the National Network "BD -BOS "in Germany, which was completed only a few years ago and which today represents the largest TETRA network in the world.

In terms of the future of mobile radio communications in general, it should be noted once again that the application of digital technology has enabled integration between UHF mobile radio communications systems of the second generation, primarily their services, which was the basic direction of further development to new mobile radio third generation systems, such as: 
1) UMTS (Universal Mobile Telecommunications Services), which is a universal mobile telecommunications system, within which satellite communications are supported, all with a set of diverse and flexible services, and

2) DAWS (Digital Advanced Wireless Services), which is a supplement to UMTS for the transition to the fourth generation of mobile systems (developed on the basis of TETRA PDO) in order to provide data transmission speeds above $2 \mathrm{Mb} / \mathrm{s}$, that is, up to ATM speeds of $155 \mathrm{Mb} / \mathrm{s}$ (Asynchronous Transfer Mode), i.e. transfer speeds above those provided by UMTS.

Note that the second generation systems include: TETRA systems, Global System Mobile Communications-GSM, then DECT (Digital Enhanced Cordeless Telecommunications), and ERMES (European Radio MEssaging System).

In this way, TETRA systems were provided with a prominent role through the third generation of mobile radio communication systems. The permission was obtained that the most modern 4G LTE network (for now), optimized for packet data transmission of high speeds and low delays, in terms of complementarity, coincides with TETRA, which speaks of the remarkable perspective of TETRA and its bright future (Swan, 2015).

Finally, it should be noted that the construction of large systems according to the TETRA standard is an extremely expensive investment which can only be made by government and state organizations, the richest companies or large operators. Namely, previous experiences and calculations show that the value per connection of the TETRA system generally ranges between 1,000 and 1,300 US $\$$. Therefore, smaller owners of the System of Functional Mobile Radio Communications in Serbia are about to look for a solution for the construction of such a system for their needs in a joint investment with large economic entities (EPS, NIS, ŽS, JKP and others), with which they will form virtual TETRA radio networks for their needs within the already built integrated TETRA system. In that sense, in their virtual TETRA network, they can then realize a special, closed numbering, and even a special application of cryptosecurity and other ways to protect the confidentiality of information (Svrzić \& Ćosović, 2002a), (ETSI, 2009).

When it comes to the part of the TETRA $V+D$ network "DIMETRA/System Release 6.2", which works for the needs of the MoD and the Serbian Armed Forces within the National TETRA network of the Ministry of Interior, the solution should also be sought in joint activities 
with the Ministry of Interior on software modernization of the network as a whole, say, in version "DIMETRA/System Release 8.1", gradually raising the hardware level of the infrastructure according to the TEDS specification (Motorola Solutions, 2013). Reaching that level and the purchase of necessary licenses will create a possibility for the MoD and the SAF, within the territorially and infrastructurally unique TETRA network with the Ministry of Interior, to form its own virtual functional network, with its numbering, its cryptographic protection by type "End to end ", with its connecting path capacities and IP connection to the Military Internet (Intranet VS) and, most importantly, its Center for Autonomous Administration, Management and Supervision (Motorola Solutions, 2016), (ETSI, 2019), (Motorola Solutions, 2020). In addition to contributing to the infrastructure of the single network, by introducing several new BSs (where in practice it has been shown that there is no quality radio coverage for the SAF), by expanding the capacity of traffic channels by adapting BS MTS-2 to MTS-4 (where practice has shown that existing capacity is unsatisfactory), and with additional successive procurement of modern TETRA radio terminals of all types (manual, transport, fixed), coupled with various peripherals and line terminals for high-speed data transmission (HSD) and multi media, it could then be an operational and functional high-efficiency UHF mobile radio network. Such a TETRA network could (of course) in peacetime, both in regular and critical and emergency situations, provide exceptional comfort to members of the $M o D$ and the Serbian Armed Forces for the implementation of the most complex tasks in the field, training grounds, airports, barracks, command facilities and operational centers, on the move, on the march, and even in the city center itself.

\section{References}

Dewaele, J. 2016. TETRA TEDS Colloquium: "User Requirements", slides 16-25 [online]. Available at: https://cupdf.com/document/tetra-enhanced-dataservice-teds-5689e2a49ebfe.html [Accessed: 10 November 2020].

-ETSI-European Telecommunications Standards Institute. 2004. TETRA PRESENTATION-13121110014-phpappp01.

-ETSI-European Telecommunications Standards Institute. 2009. EN 300 392-1 v1.4.1 TETRA Voice plus Data $(V+D)$, Part 1: General network desing [online]. Available at:

https://www.etsi.org/deliver/etsi_en/300300_300399/30039201/01.04.01_60/en_ 30039201v010401p.pdf [Accessed: 10 November 2020]. 
-ETSI-European Telecommunications Standards Institute, 2001. EN 300 392-2 v2.3.2 TETRA Voice plus Data $(V+D)$, Part 2: Air Interface (Al) [online]. Available

at: https://www.etsi.org/deliver/etsi_en/300300_300399/30039202/02.03.02_60/en_ 30039202v020302p.pdf [Accessed: 10 November 2020].

-ETSI-European Telecommunications Standards Institute. 2019. ETSI TS 100 392-2 V3.9.1 (2019-01). Technical specification. Terrestrial Trunked Radio (TETRA); Voice plus Data (V+D); Part 2: Air Interface (Al) [online]. Available at: https://www.etsi.org/deliver/etsi_ts/100300_100399/10039202/03.09.01_60/ts_1 0039202v030901p.pdf [Accessed: 10 November 2020].

Gospić, N., Tomić, I., Popović, D. \& Bogojević, D. 2010. Razvoj mobilnih komunikacija - od GSM do LTE. Belgrade: University of Belgrade - Faculty of Transport and Traffic Engineering (in Serbian). ISBN: 978-86-7395-268-0.

Jorgić, D. \& Svrzić, S. 2002. Sistem radio-veze NIS-a "M-21" (deo-V): Koncepcija za izgradnju mobilnih radio-veza NIS-a u tehnologiji digitalnog trankinga (studija). Novi Sad: Oil Industry of Serbia (in Serbian).

Krstić, M. \& Marjanović Jakovljević, M. 2018. Primena TETRA sistema u Vojsci Srbije. In: Sinteza 2018 - International Scientific Conference on Information Technology and Data Related Research, Belgrade, pp.210-216, April 20 (in Serbian). Available at: https://doi.org/10.15308/Sinteza-2018-210216.

-Motorola Solutions. 2008. DIMETRA TM System Documentation-Dimetra IP D6.2SR: Dimetra IP System Overview. October, 6866600D54-B.

-Motorola Solutions. 2013. System Release 8.1, DIMETRA TM, DIMETRA IP Compact (DIPC)/Scalable DIMETRA IP (SDIP), System Overview [online]. Available at: https://kupdf.net/download/motorola-tetra-infrastructure-technicaldocumentation-library-dimetra-ipcompact81-system-overview-

dipc_599e4563dc0d60977053a1f8_pdf [Accessed: 10 November 2020].

-Motorola Solutions. 2016. MOTOROLA DIMETRA, Applications Cataloogue, Word class solutions handpicked by a world leader in critical communications [online]. Available at: https://www.motorolasolutions.com/content/dam/msi/docs/business/product_line s/dimetra_tetra/applications/motorola_solutions/documents/static_files/dimetra_ applications_catalogue.pdf [Accessed: 10 November 2020].

-Motorola Solutions. 2020. DIMETRA TETRA infrastructure software features [online]. Available https://www.motorolasolutions.com/content/dam/msi/docs/business/products/sca da_products/_documents/static_files/dimetra_tetra_infrastructure_software_feat ures_catalog.pdf [Accessed: 10 November 2020].

Nouri, M. 2016. TEDS Colloquium: TETRA Enhanced Data Service (TEDS), slides 1-15 [online]. Available at: https://cupdf.com/document/tetraenhanced-data-service-teds-5689e2a49ebfe.html [Accessed: 10 November 2020]. 
Ovchinnikov, A.M., Vorobev, S.V. \& Sergeev, S.I. 2000. Otkrytye standarty cifrovoj trankingovoj radiosvjazi. Moscow: MCNTI, OOO Mobilnye kommunikacii (Ser. izd. Svjaz i biznes). ISBN: 5-93184-008-7. (In the original: Овчинников, А.М., Воробьев, С.В., Сергеев, С.И. 2000. Открытые стандарты цифровой транкинговой радиосвязи. Москва: МЦНТИ, ООО "Мобильные коммуникации" (Сер. изд."Связь и бизнес"). ISBN 5-93184-008-7).

-Rohde \& Schwartz. 1999a. TETRA Trans European Trunked Radio for Professional Cellular Systems [online]. Available at: https://cdn.rohdeschwarz.com/pws/dl_downloads/dl_common_library/dl_brochures_and_datashe ets/pdf_1/Tetra_e.pdf [Accessed: 10 November 2020].

-Rohde \& Schwarz. 1999b. ACCESSNET-T Digital Trunked Radio Network from Rohde \& Schwarz [online]. Available at: https://cdn.rohdeschwarz.com/pws/dl_downloads/dl_common library/dl news from rs/178/n178 _accessnet.pdf [Accessed: 10 November 2020].

Swan, D. 2015. 20 years of TETRA Technology. RadioResource International, quarter 2 [online]. Available at: https://radioamador.files.wordpress.com/2012/04/revista.pdf [Accessed: 10 November 2020].

Svrzić, S. \& Ćosović, D. 2000. Analogni tranking sistem mobilnih radioveza (special report - separat). Novi glasnik, 1, pp.3-18 (in Serbian).

Svrzić, S. \& Ćosović, D. 2002a. TETRA novi standard za digitalne tranking sisteme mobilnih radio-veza (special report - separat). Novi glasnik, 2-3, pp.3-36 (in Serbian).

Svrzić, S. \& Ćosović, D. 2002b. Comparative analysis of the standards for digital trunked mobile radio systems. Vojnotehnički glasnik/Military Technical Courier, 50(6), pp.567-588 (in Serbian). Available at: https://doi.org/10.5937/vojtehg0206567S.

25 ЛЕТ ТЕХНОЛОГИИ ТЕТRА И СТАНДАРТА СОВРЕМЕННЫХ ЦИФРОВЫХ ТРАНКИНГОВЫХ СИСТЕМ ПРОФЕССИОНАЛЬНОЙ МОБИЛЬНОЙ РАДИОСВЯЗИ

Сладжан М. Сврзич

ООО "Тесла системи“, г. Белград, Республика Сербия

РУБРИКА ГРНТИ: 49.00.00 СВЯЗЬ:

49.33.00 Сети и узлы связи;

49.33.29 Сети связи

ВИД СТАТЬИ: оригинальная научная статья

Резюме:

Введение/цель: Сегодня для построения функциональных систем мобильной радиосвязи практически исключительно используются транкинговые системы цифровой мобильной радиосвязи, основными представителями которых являются 
системы с применением стандартов TETRA. В данной статье описываются истоки и историческое развитие этого стандарта, а также деятельность ETSI и TETRA MoU в борьбе за доступность и гармонизацию радиочастотного спектра.

Методы: В статье освещены важные вопросы о происхождении и развитии стандарта TETRA 1, а также анализ характерных моментов обновленного стандарта TETRA 2.

Результаты: В данной статье описываются истоки и историческое развитие этого стандарта, а также деятельность ETSI и TETRA MoU в борьбе за доступность и гармонизацию радиочастотного спектра. В статье приведено систематизированное использование ключевых систем TETRA в мире с обзором его доли на мировом рынке по секторам, а также освещается дилемма в связи $c$ его дальнейшим развитием, находящемся на перекрестке после 25 лет своего существования. В статье также приведен базовый обзор стандарта TETRA 1 и описаны основные элементы и принципы его применения. Более подробно описываются обновленный стандарт TETRA 2 и улучшения, касающиеся способа передачи данных; особое внимание уделяется процессу сертификации фрункциональной совместимости и выходу TETRA на рынок Северной Америки. Параметры, выбранные для расширенной передачи данных в соответствии со стандартом TETRA 2TEDS, представлены и проанализированы наряду с обзором некоторых ограничений при практическом применении.

Выводы: В заключении комментируется настоящее положение современной системы TETRA и анализируется ее будущее после 25-летних разработок, подчеркивая возможность модернизации и улучшения сети TETRA для нужд Министерства внутренних дел Республики Сербия, а также Министерства обороны и Вооруженных сил Республики Сербия.

Ключевые слова: мобильная радиосвязь-MR, система мобильной радиосвязи общего пользования-PAMR, профессиональная система мобильной радиосвязи-PMR, радио-интерфрейс-Al, цифровая транкинговая система мобильной радиосвязи TETRA, TETRA расширенная служба передачи данных-TEDS, Европейский институт по стандартизации в области телекоммуникаций-ETSI. 
25 ГОДИНА ТЕТРА ТЕХНОЛОГИЈЕ И СТАНДАРДА ЗА

САВРЕМЕНЕ ТРАНКИНГ СИСТЕМЕ ФУНКЦИОНАЛНИХ

ДИГИТАЛНИХ МОБИЛНИХ РАДИО-КОМУНИКАЦИЈА

Слађан М. Сврзић

Тесла системи д.о.о., Београд, Република Србија

ОБЛАСТ: телекомуникације

ВРСТА ЧЛАНКА: оригинални научни рад

Сажетак:

Увод/циљ: За изградњу функционалних система мобилних радиокомуникација данас се готово искључиво користе дигитални системи транкинг мобилних радио-комуникација, чији је главни представник систем са применом TETRA стандарда. У раду се наводе околности настанка и историјски развој тог стандарда, са активностима ETSI и TETRA MoU у борби за доступност u хармонизацију фреквенцијског спектра.

Memoде: Описује се развој TETRA 1 стандарда и анализирају карактеристични моменти иновираног TETRA 2 стандарда.

Резултати: Наводе се околности настанка и историјски развој стандарда (са активностима ETSI и TETRA MoU у борби за доступност $u$ хармонизацију фрреквенцијског спектра). Систематизована је употреба кључних TETRA система у свету, приказан је њихов удео на светском тржишту по ресорима, а наводи се и дилема у вези с њиховим даљим развојем након 25 година постојања. Такође, представљен је основни стандард TETRA 1, описују се његови основни елементи и принципи примене. Иновирани стандард TETRA 2 и побољшања постигнута у начину преноса података детаљније су описана, наглашен је поступак сертификације интероперабилности и, с тим у вези, улазак TETRA на северноамеричко тржиште. Анализирани су параметри одабрани за напредни пренос података према TETRA 2-TEDS стандарду, а наведена су и нека ограничења током практичне примене.

Закључак: Анализиран је савремени тренутак TETRA и приказана перспектива овог стандарда. Истакнута је могућност модернизације и унапређења TETRA мреже МУП-а Србије за потребе МО и Војске Србије.

Кључне речи: мобилне радио-комуникације-MR, систем јавних мобилних радио-комуникација-PAMR, sistem funkcionalnih mobilnih radio-komunikacija-PMR, paduo-uнmepqpejc-Al, digitalni tranking sistem mobilnih radio-komunikacija-TETRA, унапређени TETRA стандард-TEDS, Европски институт за стандардизацију у телекомуникацијама-ETSI. 
Paper received on / Дата получения работы / Датум пријема чланка: 12.11.2020. Manuscript corrections submitted on / Дата получения исправленной версии работы / Датум достављања исправки рукописа: 11.03.2021

Paper accepted for publishing on / Дата окончательного согласования работы / Датум коначног прихватања чланка за објављивање: 12.03 .2021$.

(C) 2021 The Author. Published by Vojnotehnički glasnik / Military Technical Courier (www.vtg.mod.gov.rs, втг.мо.упр.срб). This article is an open access article distributed under the terms and conditions of the Creative Commons Attribution license (http://creativecommons.org/licenses/by/3.0/rs/).

(c) 2021 Автор. Опубликовано в «Военно-технический вестник / Vojnotehnički glasnik / Military Technical Courier» (www.vtg.mod.gov.rs, втг.мо.упр.срб). Данная статья в открытом доступе и распространяется в соответствии с лицензией «Creative Commons» (http://creativecommons.org/licenses/by/3.0/rs/).

() 2021 Аутор. Објавио Војнотехнички гласник / Vojnotehnički glasnik / Military Technical Courier (www.vtg.mod.gov.rs, втг.мо.упр.срб). Ово је чланак отвореног приступа и дистрибуира се у складу са Creative Commons licencom (http://creativecommons.org/licenses/by/3.0/rs/).

(c) (i) 